\title{
Learning Style Preference: Results of Repetitive Cross-Sectional Surveys in an Higher Education Institution
}

\begin{abstract}
E. Simangunsong *
School of Business and Economics, Universitas Prasetiya Mulya, Tangerang, Indonesia e-mail: elliot@pmbs.ac.id

Abstract

Using the theoretical framework of the Felder-Silverman Learning Styles Model, this study aims to understand the learning styles of middle school students entering the university to promote teaching innovation and improve the quality of the learning experience. A quantitative research method was applied through repeated cross-sectional surveys for 3 years among 2,325 students. Systematic analysis is applied to investigate respondent learning styles. Data analysis showed a significant difference in terms of the sex of students, while in terms of graduation years, the proportion of sequential students showed a significant increase from 2014 to 2016; this might imply that students from scientific or analytic backgrounds increasingly choose management schools. As expected, management students are active in character, except in accounting programs, where sensing learners are dominant. Innovative, active and visual-based learning is also preferred. Through the findings of this study, we conclude that interest in studies is related to the learning dimensions. The teaching style must follow the characteristics of the learning dimensions to provide an optimal learning experience. Here, it is important to implement an innovation-based learning process in higher education institutions.
\end{abstract}

Keywords: learning styles, innovation in teaching, quality; management, higher education, teachinglearning methodologies

\section{Introduction}

Learning styles explain how students communicate, obtain information, or respond to their learning surroundings (Sundayana, 2018; Utami \& Gafur, 2015). Knowledge of different learning styles is believed to encourage a better learning environment between teachers and students (Al Shaikh et al., 2019; McKenna et al., 2018). Most higher education students are unconventional learners who prefer learning through activities such as exploration, field work, role playing, and creation of innovative ideas. Millennials are generally technologically savvy and are the most important workforce in the future (Bernardes et al., 2019). These findings suggest the urgency for lecturers or university administrators to survey the instructors' existing teaching methods and basic teaching skillsMismatch between a teacher's learning style and students' favored learning style may cause students' disappointment, a less-ideal class situation for knowledge learning, and students' powerlessness to accomplish higher education performance. Since the coronavirus pandemic (COVID-19) hit many countries in the world in early 2020, including Indonesia, the Indonesian Government is implementing distance learning (PJJ) where teaching and learning activities must be conducted at home through online format. Implemented PJJ has created many problems between teachers and students from various regions in Indonesia. The lack of physical face-to-face demands a creative attitude challenge for teachers to provide learning methods for PJJ, so they can keep students' learning desires high. However, there are many cases of failure in the implementation of this PJJ. Therefore, scientific studies are needed to identify student learning so that the results of research can help teachers in preparing teaching materials.

On the other hand, virtual learning activities from home increase parents' awareness of how the learning process carried out by a teacher makes their children understand the lesson well. Parents can act as a companion and bridge between teachers and students during this virtual teaching period (Nightingale et al., 2017; Rivas et al., 2021). If parents

\footnotetext{
${ }^{*}$ Corresponding author.

Received 21 October 2019; Accepted 20 September 2020; Available online 01 December 2020

(C) 2020 JPI. All Rights Reserved
}

Jurnal Pendidikan Indonesia (JPI) | 730 
understand their child's learning styles, it will be easier for parents to accompany and support children's learning. There are many reading materials about learning and teaching, but readings from well-organized study-based scientific journals are still lacking. Comprehension of learning styles is useful for students to identify their own qualities and shortcomings and to gain from them. Teachers may likewise use these data to distinguish one-of-a-kind learning styles for specific students and afterward adjust his/her training styles to coordinate learning styles for that specific student to strengthen their learning forms (Chimmalgi, 2018; Hussain \& Ayub, 2012; Islam, 2019)

The research and report to date explain the urgency of further research to study student learning styles, especially since the emergence of the Covid-19 pandemic, it has led to increased virtual learning and many problems found in the field. In addition, further empirical studies are also needed to obtain knowledge that teachers can use to develop their learning methods. The objectives of this research are twofold. Firstly, we strive to test and understand student learning styles in terms of gender, year of high school graduation, and desired undergraduate programs in management or accounting. The second objective is to identify new innovation in teaching and learning delivery. Learning styles as characteristic strengths and preferences in the ways students take in and process information (Putri et al., 2019; Sakti et al., 2019). Even though it is difficult to identify, learning styles are likely to play tremendous roles in influencing educational achievement. An excellent education system offers college students learning in both their favored and less preferred modes of learning (Lee et al., 2020) Consequently, the goal of lecturer improvement is to equip instructors with the competencies of teaching associated with every studying style in order to teach effectively as expert lecturers. This may better meet the needs of college students whose learning styles are ignored through the use of traditional pedagogy.

Students with an autonomous learning style are likewise more prone to perform well in Internet learning courses, which require them to be more proactive than traditional, inperson classroom courses. Autonomous students are regularly thought of as self-observers, commonly inclined to work alone on singular assignments. They are not detached nor do they need activity; rather, they freely achieve self-determined learning and subject perception. Community students lean toward collective exercises and testing errands, for example, amass discourses and undertakings, field outings, and open-finished issues or gathering introductions. There is still doubt whether any learning style model can be applied in practice (Islam, 2019). There are still questions left for most of the learning style model findings about how that model can affect learning. There is also a research gap on how the attitude of millennial workers towards learning or training methods in a company (Bernardes et al., 2019). Further studies are still needed to understand how understanding this learning style can increase the attractiveness of young generation applicants to the company.

Research conducted by (Adedeji et al., 2020) stated that which emphasized the need for further and long-term research efforts to ensure the consistency of the benefits of active learning for students and if there are inconsistencies, what activities need to be designed to motivate and increase the level of student understanding over time.This study aims to understand the learning styles of middle school students entering the university to promote teaching innovation and improve the quality of the learning experience.

\section{Method}

The objective of this research is to investigate students' learning styles in 2016 and compare the results with surveys administered in 2014 and 2015. The design of research involves comparative, repeated cross-sectional surveys. The research process used follows phases of studying the literature, collecting data using survey instruments, verifying data, analyzing data, and answering research questions. The quantitative research method is selected for this study because it is a popular method applied in previous studies. The population of the study includes students who graduated high school during the survey period. The number of respondents is 2,325. Data were entered and analyzed with the Statistical Package for Social Sciences (SPSS). This research applies several techniques for data analysis. 
The first technique is descriptive analysis. Here, the data are summarized with the purpose of describing the sampled data and understanding the profile of the respondents. The second technique is the Pearson Chi-Square Test of association to examine independence across two categorical variables. These tests help to explain whether a particular learning dimension is association with factors such as gender, year of graduation, and field of study interest. The chi-square test is also applied to check uniformity of sample distribution (goodness of fit test). The third technique is Multiple Correspondence Analysis (MCA); this is a data dimension reduction and graphical exploration technique for categorical data that allows researchers to reveal patterns or categories in data. Finally, a binary logistics regression technique is also applied to study the effects of eight learning dimensions regarding the likelihood that a participant is male or female.

\section{Results and Discussion}

Descriptive statistics are used to examine the comparability of samples in years 2014, 2015, and 2016 in terms of gender, year of high school graduation, school location, and interest in higher education study program. Moore et al. (2015) suggested testing the significance of the difference between survey years using design-adjusted $\mathrm{X} 2$ analyses for categorical variables. Table 1 presents year of high school graduation of respondents. There are 2,325 high school graduates distributed relatively uniformly across the three years of data. The chi-square test has a large $p$-value (fail to reject null hypotheses); this confirms that the number of samples for each year of data collection is consistent with expectations. The large number of samples also enables the researcher to conduct comparative analysis.

Table 1. Year of High School Graduation

\begin{tabular}{rcccr}
\hline Year & Frequency & Percent & & \\
\hline 2014 & 775 & 33.3 & Chi-Square & 0.740 \\
2015 & 699 & 30.1 & Asymp. Sig. & .691 \\
2016 & 851 & 36.6 & & \\
\hline Total & $\mathbf{2 3 2 5}$ & $\mathbf{1 0 0 . 0}$ & & \\
\hline
\end{tabular}

In terms of gender, there are more male respondents compared to female respondents. However, the chi-square test has a large $p$-value which means it is reasonable to assume that the proportion of male respondents is similar to female respondents. This result also suggests that the data are relevant for gender analysis. The result gender of respondents can be seen in Table 2.

Table 2. Gender of Respondents

\begin{tabular}{lcccr}
\hline & Frequency & Percent & & \\
\hline Male & 1316 & 56.6 & Chi-Square & 1.960 \\
Female & 1009 & 43.4 & Asymp. Sig. & .162 \\
\hline Total & $\mathbf{2 3 2 5}$ & $\mathbf{1 0 0 . 0}$ & & \\
\hline
\end{tabular}

Table 3 presents the domiciles of the respondents. Chi-square test produces a very small p-value (Reject $\mathrm{HO}$ ), which means the respondents' domiciles are not uniformly distributed. Most respondents (70\%) live in Greater Jakarta (Jabodetabek). It is reasonable to assume that the location of the survey in Greater Jakarta is the main reason for the large sample from this area; most students tend to find schools closer to where they live. Moreover, Greater Jakarta is the capital city of Indonesia, and many prestigious institutions are located in this area. The standard of living in Greater Jakarta City includes modern and well-equipped infrastructure, comparable to the living standard in cities in developed 
countries. This may enable comparison of this study's findings with research in other such cities

Table 3. Domicile of respondents

\begin{tabular}{lcccr}
\hline & Frequency & Percent & & \\
\hline Jabodetabek & 1646 & 70.8 & & \\
Jawa Barat & 262 & 11.3 & & \\
Jawa Tengah & 131 & 5.6 & Chi-Square & 370.700 \\
Yogyakarta & 13 & .6 & Asymp. Sig. & .000 \\
Jawa Timur & 77 & 3.3 & & \\
Sumatera & 99 & 4.3 & & \\
Kalimantan & 52 & 2.2 & & \\
Sulawesi & 13 & .6 & & \\
Bali,NTB,NTT & 15 & .6 & & \\
Maluku \& Papua & 8 & .3 & & \\
Foreign Countries & 9 & $\mathbf{4}$ & & \\
\hline Total & $\mathbf{2 3 2 5}$ & $\mathbf{1 0 0 . 0}$ & & \\
\hline
\end{tabular}

In terms of gender, the results of this study revealed that male students have significant differences in three learning-pair attributes compared to female students. Chisquare test shows that gender demonstrates no difference in terms of active versus reflective learners, but provides enough evidence to assume that male learners are different from female learners in terms of sensing or intuitive, visual or verbal, and sequential or global learning. The results of Chi-square test of association between gender and learning-pair attributes can be seen in Table 4.

Table 4. Chi-square test of association between gender and learning-pair attributes

\begin{tabular}{lccrr}
\hline Gender & Active & Reflective & & \\
Male & $83.9 \%$ & $16.1 \%$ & Chi-square & .009 \\
Female & $83.7 \%$ & $16.3 \%$ & Sig. & .925 \\
\hline Gender & Sensing & Intuitive & & \\
Male & $74.3 \%$ & $25.7 \%$ & Chi-square & 7.523 \\
Female & $79.2 \%$ & $20.8 \%$ & Sig. & $.006^{*}$ \\
\hline Gender & Visual & Verbal & & \\
Male & $90.6 \%$ & $9.4 \%$ & Chi-square & 7.807 \\
Female & $86.9 \%$ & $13.1 \%$ & Sig. & $.005^{*}$ \\
\hline Gender & Sequential & Global & & \\
Male & $42.8 \%$ & $57.2 \%$ & Chi-square & 35.298 \\
Female & $55.2 \%$ & $44.8 \%$ & Sig. & $.000^{*}$ \\
\hline * The Chi-square statistic is significant at the 0.05 level & & &
\end{tabular}

${ }^{*}$. The Chi-square statistic is significant at the 0.05 level.

As seen in Table 4, male students have higher proportions of intuitive, visual, and global learners, while female students have higher proportions of intuitive, verbal, and sequential learners. In terms of year of high school graduation, the chi-square test shows that there is no change in active-reflective dimension and sequential-global dimensions. The test, however, shows association for the other dimensions. There is sufficient evidence that 
the proportion of sequential learners increased from 2014 to 2016; this may imply that students from a science or analytical background increasingly preferred management school. We may also assume that the proportion of visual students is consistently higher than verbal students across these three graduation years. The proportion of sequential learners is similar to that of global learners can be seen in Table 5.

Table 5. Chi-square test of association between year of high school graduation and learning dimensions

\begin{tabular}{|c|c|c|c|c|}
\hline Year of graduation & Active & Reflective & & \\
\hline 2014 & $85.2 \%$ & $14.8 \%$ & Chi-square & 4.157 \\
\hline 2015 & $84.8 \%$ & $15.2 \%$ & Sig. & .125 \\
\hline 2016 & $81.8 \%$ & $18.2 \%$ & & \\
\hline Year of graduation & Sensing & Intuitive & & \\
\hline 2014 & $72.0 \%$ & $28.0 \%$ & Chi-square & 15.391 \\
\hline 2015 & $76.7 \%$ & $23.3 \%$ & Sig. & $.000^{*}$ \\
\hline 2016 & $80.3 \%$ & $19.7 \%$ & & \\
\hline Year of graduation & Visual & Verbal & & \\
\hline 2014 & $89.8 \%$ & $10.2 \%$ & Chi-square & 7.753 \\
\hline 2015 & $86.3 \%$ & $13.7 \%$ & Sig. & $.021^{\star}$ \\
\hline 2016 & $90.5 \%$ & $9.5 \%$ & & \\
\hline Year of graduation & Sequential & Global & & \\
\hline 2014 & $48.3 \%$ & $51.7 \%$ & Chi-square & 1.884 \\
\hline 2015 & $46.2 \%$ & $53.8 \%$ & Sig. & .390 \\
\hline 2016 & $49.7 \%$ & $50.3 \%$ & & \\
\hline
\end{tabular}

The majority of the respondents are interested in a BSC in Business (61\%), followed by BSC in Marketing (20\%), BSC in Finance (10\%), and BSC in Accounting (9\%). Business studies are dominant, because entrepreneurship education has been booming in recent years in Indonesia. Therefore, it is important to understand the learning style of entrepreneurship students; many of them will influence Indonesian economy in the future.

Table 6 shows a significant chi-square result for all four tests. This means that interest in study has an association with learning dimensions. As predicted, students who undergo management programs are mainly active, sensing, and visual learners. Some of them are either sequential or global learners. This finding highlights the importance of implementing an innovation-based learning process in higher education institutions. The results of Chi-square test of association between interest of study and learning dimensions can be seen in Table 6.

Table 6. Chi-square test of association between interest of study and learning dimensions

\begin{tabular}{lllll}
\hline Interest of Study & Active & Reflective & & \\
\hline BSCA & $73.00 \%$ & $27.00 \%$ & Chi-square & 39.072 \\
BSCB & $84.80 \%$ & $15.20 \%$ & Sig. & $.000^{*}$ \\
BSCF & $76.70 \%$ & $23.30 \%$ & & \\
BSCM & $89.50 \%$ & $10.50 \%$ & & \\
\hline Interest of Study & Sensing & Intuitive & & 36.767
\end{tabular}




\begin{tabular}{lllll} 
BSCB & $74.30 \%$ & $25.70 \%$ & Sig. & $.000^{*}$ \\
BSCF & $86.00 \%$ & $14.00 \%$ & & \\
BSCM & $72.30 \%$ & $27.70 \%$ & & \\
\hline Interest of Study & Visual & Verbal & & 19.344 \\
\hline BSCA & $81.40 \%$ & $18.60 \%$ & Chi-square & $.000^{*}$ \\
BSCB & $90.60 \%$ & $9.40 \%$ & Sig. & \\
BSCF & $85.60 \%$ & $14.40 \%$ & & 20.034 \\
BSCM & $89.20 \%$ & $10.80 \%$ & & $.000^{*}$ \\
\hline Interest of Study & Sequential & Global & & \\
\hline BSCA & $60.90 \%$ & $39.10 \%$ & Chi-square & \\
BSCB & $46.90 \%$ & $53.10 \%$ & Sig. & \\
BSCF & $52.50 \%$ & $47.50 \%$ & & \\
BSCM & $44.00 \%$ & $56.00 \%$ & & \\
\hline
\end{tabular}

${ }^{*}$ The Chi-square statistic is significant at the 0.05 level.

The next analysis determines the strength and direction of the eight learning dimensions. The bivariate correlations matrix procedure in SPSS is used to compute the pairwise associations for variables and displays the results in a matrix. Table 7 presents a summary of the findings.

Table 7. Correlation matrix of eight leaning dimensions $(n=2325)$

\begin{tabular}{|c|c|c|c|c|c|c|c|c|}
\hline & $\begin{array}{l}\text { Activ } \\
\text { e }\end{array}$ & $\begin{array}{l}\text { Reflectiv } \\
\text { e }\end{array}$ & $\begin{array}{l}\text { Sensin } \\
\mathbf{g}\end{array}$ & $\begin{array}{l}\text { Intuitiv } \\
\mathrm{e}\end{array}$ & $\begin{array}{l}\text { Visua } \\
\text { I }\end{array}$ & $\begin{array}{l}\text { Verba } \\
\text { I }\end{array}$ & $\begin{array}{l}\text { Sequentia } \\
\text { I }\end{array}$ & $\begin{array}{l}\text { Globa } \\
\text { I }\end{array}$ \\
\hline Active & & $-* *$ & - & + & $+^{* *}$ & $-* *$ & - & + \\
\hline Reflective & & & + & - & $-* *$ & $+{ }^{* *}$ & + & - \\
\hline Sensing & & & & $-* *$ & - & + & $+^{* *}$ & $-* *$ \\
\hline Intuitive & & & & & + & - & $-* *$ & $+^{* *}$ \\
\hline Visual & & & & & & $-* *$ & - & + \\
\hline Verbal & & & & & & & + & - \\
\hline $\begin{array}{l}\text { Sequentia } \\
\text { I }\end{array}$ & & & & & & & & $-* *$ \\
\hline Global & & & & & & & & \\
\hline
\end{tabular}

** Significant correlation

Table 7 shows that four dimensions, i.e., active, intuitive, visual and global, demonstrate positive correlation with each other and are negatively correlated to the other dimensions. On the other hand, the reflective, sensing, verbal, and sequential dimensions demonstrate positive correlation with each other and negative correlation with the other four dimensions. Based on this finding, we can categorize the eight dimensions as there are two major dimensions. The first consists of active, intuitive, visual, and global dimensions. We named this category "unconventional learner." The second major dimension consists of reflective, sensing, verbal, and sequential. We named this category "conventional learner." There are two sub-categories for each major dimension. The unconventional learner belongs to the active-visual category and the intuitive-global category. The conventional learner belongs to the reflective-verbal category and the sensing-sequential category. Categories of Eight Learning Dimensions can be seen in Figure 1. 


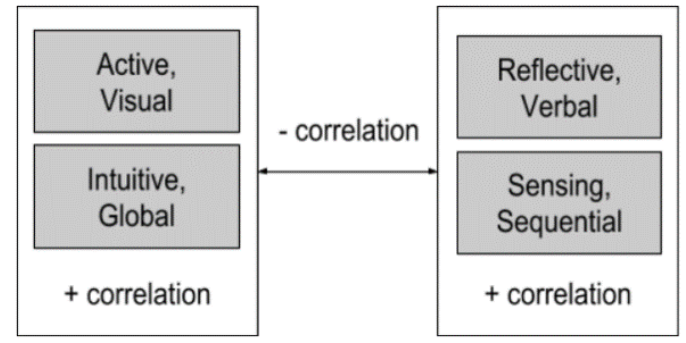

Figure 1. Categories of Eight Learning Dimensions

Using Figure 1 as the base of analysis, Table 8 presents descriptive statistics of the respondents. For major category, $12.77 \%$ of respondents are unconventional learners (active, visual, intuitive and global learners), and only $1.59 \%$ of respondents are conventional learners (reflective, verbal, sensing, and sequential learners). Most unconventional learners are male students and conventional learners are female students. Chi-square test shows a small $p$-value, which means unconventional and conventional learners have association with gender.

From 2,325 samples, $76.39 \%$ are active and visual learners followed by $41.08 \%$ sensing and sequential learners. The other two categories have significantly lower proportions (16.47\% and 3.57\%, respectively). Chi-square test also shows significant result for all four categories. The result of Chi-square test of association between gender and categories of learning dimension can be seen in Table 8.

Table 8. Chi-square test of association between gender and categories of learning dimension

\begin{tabular}{|c|c|c|c|c|c|}
\hline & \multirow[b]{2}{*}{$\mathbf{N}$} & \multirow[b]{2}{*}{$\%$ Total } & \multicolumn{2}{|c|}{ Gender } & \multirow[b]{2}{*}{ Test of Association } \\
\hline & & & Male & Female & \\
\hline All Respondents & 2325 & $100 \%$ & $56.60 \%$ & $43.40 \%$ & \\
\hline \multicolumn{6}{|c|}{ Major Category } \\
\hline $\begin{array}{l}\text { Active, Visual, Intuitive, and } \\
\text { Global Learners }\end{array}$ & 297 & $12.77 \%$ & $64.00 \%$ & $36.00 \%$ & $\begin{array}{l}\text { Chi-square }=7.531 \\
\text { Sig. }(2 \text {-sided })=0.006\end{array}$ \\
\hline $\begin{array}{l}\text { Reflective, Verbal, Sensing, } \\
\text { and Sequential Learner }\end{array}$ & 37 & $1.59 \%$ & $37.80 \%$ & $62.20 \%$ & $\begin{array}{l}\text { Chi-square }=5.389 \\
\text { Sig. }(2 \text {-sided })=0.020\end{array}$ \\
\hline \multicolumn{6}{|c|}{ Sub Category } \\
\hline Active and Visual Learner & 1776 & $76.39 \%$ & $57.50 \%$ & $42.50 \%$ & $\begin{array}{r}\text { Chi-square }=2.722 \\
\text { Sig. }(2 \text {-sided })=0.099\end{array}$ \\
\hline Intuitive and Global Learner & 383 & $16.47 \%$ & $65.50 \%$ & $34.50 \%$ & $\begin{array}{l}\text { Chi-square }=14.896 \\
\text { Sig. }(2 \text {-sided })=0.000\end{array}$ \\
\hline $\begin{array}{l}\text { Reflective and Verbal } \\
\text { Learner }\end{array}$ & 83 & $3.57 \%$ & $50.60 \%$ & $49.40 \%$ & $\begin{array}{l}\text { Chi-square }=1.261 \\
\text { Sig. }(2 \text {-sided })=0.261\end{array}$ \\
\hline $\begin{array}{l}\text { Sensing and Sequential } \\
\text { Learner }\end{array}$ & 955 & $41.08 \%$ & $49.80 \%$ & $50.20 \%$ & $\begin{array}{l}\text { Chi-square }=30.144 \\
\text { Sig. }(2 \text {-sided })=0.000\end{array}$ \\
\hline
\end{tabular}

Table 9 shows that there is enough evidence to support association between interest of study in management and unconventional learners, but not enough evidence for conventional learners. The result of chi-square test also significantly falls below other categories except reflective and verbal learners. The result of chi-square test of association between interest of study and categories of learning dimension can be seen in Table 9 
Table 9. Chi-square test of association between interest of study and categories of learning dimension

\begin{tabular}{|c|c|c|c|c|c|c|c|}
\hline & \multirow[b]{2}{*}{$\mathbf{N}$} & \multirow[b]{2}{*}{$\begin{array}{c}\% \\
\text { Total } \\
\end{array}$} & \multicolumn{4}{|c|}{ Interest of study } & \\
\hline & & & BSCA & BSCB & BSCF & BSCP & \\
\hline All Respondents & 2325 & $100 \%$ & $9.20 \%$ & $61.00 \%$ & $10.20 \%$ & $19.60 \%$ & \\
\hline \multicolumn{8}{|l|}{ Major Category } \\
\hline $\begin{array}{l}\text { Active, Visual, } \\
\text { Intuitive, and } \\
\text { Global Learner }\end{array}$ & 297 & $12.77 \%$ & $3.00 \%$ & $66.30 \%$ & $6.10 \%$ & $24.6 \%$ & $\begin{array}{c}\text { Chi-square = } \\
25.775 \\
\text { Sig. }(2- \\
\text { sided })=0.000\end{array}$ \\
\hline $\begin{array}{l}\text { Reflective, } \\
\text { Verbal, Sensing, } \\
\text { and Sequential } \\
\text { Learner }\end{array}$ & 37 & $1.59 \%$ & $18.90 \%$ & $54.10 \%$ & $10.80 \%$ & $16.2 \%$ & $\begin{array}{c}\text { Chi-square }=4.335 \\
\text { Sig. }(2- \\
\text { sided })=0.227\end{array}$ \\
\hline \multicolumn{8}{|l|}{ Sub Category } \\
\hline $\begin{array}{l}\text { Active and } \\
\text { Visual Learner }\end{array}$ & 1776 & $76.39 \%$ & $7.30 \%$ & $63.00 \%$ & $8.70 \%$ & $20.9 \%$ & $\begin{array}{c}\text { Chi-square = } \\
57.305 \\
\text { Sig. }(2- \\
\text { sided })=0.000\end{array}$ \\
\hline $\begin{array}{l}\text { Intuitive and } \\
\text { Global Learner }\end{array}$ & 383 & $16.47 \%$ & $3.40 \%$ & $66.60 \%$ & $6.80 \%$ & $23.2 \%$ & $\begin{array}{c}\text { Chi-square = } \\
27.557 \\
\text { Sig. }(2- \\
\text { sided })=0.000\end{array}$ \\
\hline $\begin{array}{l}\text { Reflective and } \\
\text { Verbal Learner }\end{array}$ & 83 & $3.57 \%$ & $15.70 \%$ & $57.80 \%$ & $9.60 \%$ & $16.9 \%$ & $\begin{array}{c}\text { Chi-square }=4.319 \\
\text { Sig. }(2- \\
\text { sided })=0.229\end{array}$ \\
\hline $\begin{array}{l}\text { Sensing and } \\
\text { Sequential } \\
\text { Learner }\end{array}$ & 955 & $41.08 \%$ & $12.50 \%$ & $58.20 \%$ & $12.30 \%$ & $17.1 \%$ & $\begin{array}{c}\text { Chi-square }= \\
32.428 \\
\text { Sig. }(2- \\
\text { sided })=0.000\end{array}$ \\
\hline
\end{tabular}

Further analysis is conducted to confirm the categorization of the dimensions. Because those data are nominal, a multiple correspondence analysis is conducted. Multiple Correspondence Analysis (MCA) is a well-known multivariate technique for data dimensionality reduction and graphical exploration, especially for categorical In correspondence analysis, mapping variables in a two-dimensional space allows researchers to simply find dependencies among variables, thereby providing information on segmenting and interpreting consumer groups. Correspondence analysis is an exploratory data analysis technique and is useful for revealing patterns in data; the method and the data do the work and define the nature of the relationships.

Table 10 shows the model summary. Cronbach's Alpha value $=0.716$, and this represents enough reliability to analyze the data further. About $67 \%$ of the variance in the data are accounted for by the solution: $35.8 \%$ by the first dimension and $31.1 \%$ by the second. The result of Multiple Correspondence Analysis (MCA) can be seen in Table 10 
Table 10. Multiple Correspondence Analysis (MCA)

\begin{tabular}{lcccc}
\hline \multirow{2}{*}{ Dimension } & \multirow{2}{*}{ Cronbach's Alpha } & \multicolumn{3}{c}{ Variance Accounted For } \\
\cline { 3 - 5 } & & Total (Eigenvalue) & Inertia & \% of Variance \\
\hline 1 & 0.744 & 2.865 & 0.358 & 35.806 \\
2 & 0.684 & 2.49 & 0.311 & 31.122 \\
Total & & 5.354 & 0.669 & \\
Mean & $.716^{\mathrm{a}}$ & 2.677 & 0.335 & 33.464 \\
\hline
\end{tabular}

a Mean Cronbach's Alpha is based on the mean Eigenvalue.

We would also like to test whether gender (as a dependent variable) can be determined by learning dimensions. A binary logistic regression was performed to identify the effects of eight learning dimensions on the likelihood that a participant is male or female. We will use the forward stepwise regression method in SPSS. A binary logistic regression (often referred to simply as logistic regression), predicts the probability that an observation falls into one of two categories of a dichotomous dependent variable based on one or more independent variables that can be either continuous or categorical.

Gender is used as a dependent variable and the scores of eight learning dimensions (active, reflective, sensing, intuitive, visual, verbal, sequential, and global) as independent variables. Binary logistics regression is selected, because the dependent variable has nominal value $(0=$ male, $1=$ female). All samples $(n=2325)$ are used for analysis. The result is presented in the Table 11.

Table 11. Model Summary

\begin{tabular}{cccc}
\hline Step & $\mathbf{- 2}$ Log likelihood & Cox \& Snell R Square & Nagelkerke R Square \\
\hline 1 & $3138.710^{\mathrm{a}}$ & 0.019 & 0.025 \\
2 & $3111.351^{\mathrm{a}}$ & 0.03 & 0.04 \\
\hline${ }^{\mathrm{a} E s t i m a t i o n ~ t e r m i n a t e d ~ a t ~ i t e r a t i o n ~ n u m b e r ~} 3$ because parameter estimates changed \\
by less than .001.
\end{tabular}

In the binary regression model, the coefficient of determination, $\mathrm{R}^{2}$ - the proportion of variance in the dependent variable associated with the predictor (independent) variables - is approximated with Cox and Snell's $R^{2}$ or Nagelkerke's $R^{2}$. The $R^{2}$ values tell us approximately how much variation in the outcome is explained by the model. Therefore, the explained variation in the dependent variable based on our model ranges from $3 \%$ to $4 \%$, depending on whether you reference the Cox \& Snell $R^{2}$ or Nagelkerke $R^{2}$ methods, respectively.

Table 12. Hosmer and Lemeshow Test

\begin{tabular}{cccc}
\hline Step & Chi-square & df & Sig. \\
\hline 1 & 2.705 & 6 & 0.845 \\
2 & 4.162 & 8 & 0.842 \\
\hline
\end{tabular}

The Hosmer \& Lemeshow test (Table 12) of the goodness of fit suggests the model is a good fit to the data as $p=0.845$ (>.05). The Hosmer \& Lemeshow statistic indicates a poor fit if the significance value is less than 0.05. The Classification Table (See Table 13) shows the practical results of using the logistic regression model. As demonstrated, our model is now correctly classifying the outcome for $59.3 \%$, or 3 out of 5 cases, as correctly predicted. 
Table 13. Classification Table for Gender

\begin{tabular}{lccc}
\hline Observed & \multicolumn{2}{c}{ Predicted Gender } & Percentage Correct \\
\hline & Male & Female & \\
Male & 1092 & 224 & 83 \\
Female & 723 & 286 & 28.3 \\
Overall Percentage & & & 59.3 \\
\hline
\end{tabular}

Table 14 shows the contribution of each independent variable to the model and its statistical significance. This table provides the regression coefficient (B), the Wald statistic (to test the statistical significance), and the all-important Odds Ratio (Exp (B)) for each variable category. The Wald test ("Wald" column) is used to determine statistical significance for each independent variable. The statistical significance of the test is found in the "Sig." column. From these results, we can see that the visual $(p=.000)$ and global $(p=.000)$ dimensions contribute significantly to the model/prediction. The $b$ coefficients for visual and global variables are significant and negative, indicating that increased scores in the visual or global dimensions are associated with increased probability that the learner is male.

Table 14. Variables in the Equation

\begin{tabular}{llcccccc}
\hline & & B & S.E. & Wald & df & Sig. & Exp(B) \\
\hline Step $1^{\mathrm{a}}$ & Global.Score & -0.143 & 0.022 & 42.664 & 1 & .000 & 0.866 \\
& Constant & 0.532 & 0.128 & 17.14 & 1 & .000 & 1.702 \\
Step $2^{\mathrm{b}}$ & Visual.Score & -0.109 & 0.021 & 27.046 & 1 & .000 & 0.896 \\
& Global.Score & -0.137 & 0.022 & 38.572 & 1 & .000 & 0.872 \\
& Constant & 1.388 & 0.21 & 43.517 & 1 & .000 & 4.007 \\
\hline
\end{tabular}

a Variable(s) entered on step 1: Global.Score.

${ }^{b}$ Variable(s) entered on step 2: Visual.Score.

The Table 14 shows that visual and global are two variables that have small $p$-values and hence can explain the variable of gender. This is the second out of eight dimensions that can explain gender. The meaning of a logistic regression coefficient is not as straightforward as that of a linear regression coefficient. While $B$ is convenient for testing the usefulness of predictors, $\operatorname{Exp}(B)$ is easier to interpret. $\operatorname{Exp}(B)$ represents the ratio change in the odds of the event of interest for a one-unit change in the predictor. For example, $\operatorname{Exp}(B)$ for visual is equal to 0.896 , which means an increased value in the visual score will increase the chance of the female gender by 0.896 , all other aspects being equal.

The results of this study confirm previous research conducted by (Bayrak, 2012) where apart from gender differences, all students like active learning styles. However, despite having the same preference for active learning, this study found sufficient evidence that male students' active learning style scores were higher than female students. On the other hand, there is a significant difference in learning styles where female students prefer systematic (sequential) learning styles compared to male students who prefer learning with a global (holistic) approach. Female students also prefer verbal learning styles than male students. Male students prefer the experience of learning through active experimentation and are attracted to the "big picture" that is very important to them. Millennial students (generation-z) like the learning process that is team-oriented and has a collaborative attitude, a learning style pattern that is not different from the previous generation (generation-y) (Dilullo et al., 2011). 


\section{Conclusion}

The results of the analysis show that the interest of study is associated with learning dimensions. Students from science or analytical backgrounds also increasingly preferred management school. Most respondents are active, sensing, and visual learners. Therefore, it is important to implement an innovation-based learning process in higher education institutions. This study proposes a new and different categorization of learning dimension model compared to the classification model. We identify four dimensions (active, intuitive, visual, and global) that can be combined as one, referred to as the unconventional learner. The other four dimensions (reflective, sensing, verbal, and sequential) represent the conventional learner. It is interesting to note that gender is associated with unconventional and conventional learners

\section{References}

Adedeji, S. B., Rahman, M. M., Abdul, M. B., Ghani, M. F. B. A., Uddin, M. J., \& Rahaman, M. S. (2020). Innovative Teaching Methods and Entrepreneurship Education: a Synthesised Literature Review. Educational Administration Research and Review, 2(1), 1807-1813. https://doi.org/10.17509/earr.v2i1.21713

Al Shaikh, A., Aldarmahi, A. A., AL-Sanie, E., Subahi, A., Ahmed, M. E., Hydrie, M. Z., \& AlJifree, H. (2019). Learning styles and satisfaction with educational activities of Saudi Health Science University Students. Journal of Taibah University Medical Sciences, 14(5), 418-424. https://doi.org/10.1016/j.jtumed.2019.07.002

Bayrak, B. K. (2012). A Study on Learning Styles of Secondary School Student's According to Gender and Class Level. Procedia - Social and Behavioral Sciences, 46, 843-847. https://doi.org/10.1016/j.sbspro.2012.05.210

Bernardes, R. F., Guzzo, R. F., \& Madera, J. M. (2019). Millennial Attitudes Toward Online and Traditional Training Methods: The Role of Training Utility and Satisfaction. Cornell Hospitality Quarterly, 60(4), 320-334. https://doi.org/10.1177/1938965519843488

Chimmalgi, M. (2018). Off-line virtual microscopy in teaching histology to the undergraduate medical students: do the benefits correlate with the learning style preferences? Journal of the Anatomical Society of India, 67(2), 186-192. https://doi.org/10.1016/j.jasi.2018.11.010

Dilullo, C., Mcgee, P., \& Kriebel, R. M. (2011). Demystifying the Millennial student: A reassessment in measures of character and engagement in professional education. Anatomical Sciences Education, 4(4), 214-226. https://doi.org/10.1002/ase.240

Hussain, N., \& Ayub, N. (2012). Learning Styles of Students and Teaching Styles of Teachers in Business Education: A Case Study of Pakistan. Procedia - Social and Behavioral Sciences, 69(Iceepsy), 1737-1740. https://doi.org/10.1016/j.sbspro.2012.12.122

Islam, N. (2019). Learning Styles: Diverse Avenues to Learning. International Journal of Research in Engineering, IT and Social Sciences, 09(01), 73-85. http://indusedu.org/pdfs/IJREISS/IJREISS_2609_75966.pdf

Lee, J. X., Hathim, A., Azman, A., Ng, J. Y., \& Shareela, N. A. (2020). Reflection of connectivism in medical education and learning motivation during COVID-19. MedRxiv. https://doi.org/https://doi.org/10.1101/2020.07.07.20147918

McKenna, L., Copnell, B., Butler, A. E., \& Lau, R. (2018). Learning style preferences of Australian accelerated postgraduate pre-registration nursing students: A crosssectional survey. Nurse Education in Practice, 28(January), 280-284. https://doi.org/10.1016/j.nepr.2017.10.011

Nightingale, R., Wirz, L., Cook, W., \& Swallow, V. (2017). Collaborating With Parents of 
Children With Chronic Conditions and Professionals to Design, Develop and Pre-pilot PLAnT (the Parent Learning Needs and Preferences Assessment Tool). Journal of Pediatric Nursing, 35, 90-97. https://doi.org/10.1016/j.pedn.2017.03.008

Putri, F. E., Amelia, F., \& Gusmania, Y. (2019). Hubungan Antara Gaya Belajar dan Keaktifan Belajar Matematika Terhadap Hasil Belajar Siswa. Edumatika: Jurnal Riset Pendidikan Matematika, 2(2), 83. https://doi.org/10.32939/ejrpm.v2i2.406

Rivas, A., González-Briones, A., Hernández, G., Prieto, J., \& Chamoso, P. (2021). Artificial neural network analysis of the academic performance of students in virtual learning environments. Neurocomputing, 423(xxxx), 713-720. https://doi.org/10.1016/j.neucom.2020.02.125

Sakti, T. K., Hairunisya, N., \& Sujai, I. S. (2019). Pengaruh Kompetensi Pedagogik Guru dan Gaya Belajar Siswa Terhadap Prestasi Belajar Siswa Pada Mata Pelajaran IPS. Jurnal Pendidikan IImu Sosial, 28(1), 53. https://doi.org/10.17509/jpis.v28i1.12818

Sundayana, R. (2018). Kaitan antara Gaya Belajar, Kemandirian Belajar, dan Kemampuan Pemecahan Masalah Siswa SMP dalam Pelajaran Matematika. Mosharafa: Jurnal Pendidikan Matematika, 5(2), 75-84. https://doi.org/10.31980/mosharafa.v5i2.262

Utami, P. S., \& Gafur, A. (2015). Pengaruh Metode Pembelajaran Dan Gaya Belajar Siswa Terhadap Hasil Belajar IPS Di SMP Negeri Di Kota Yogyakarta. Harmoni Sosial: Jurnal Pendidikan IPS, 2(1), 97-103. https://doi.org/10.21831/hsjpi.v2i1.4622 